\title{
EFFECT OF SEEDING RATE ON SOIL WATER CONSUMPTION, YIELD AND QUALITY UNDER WIDE SPACE SOWING OF DRYLAND WINTER WHEAT ON THE LOESS PLATEAU IN CHINA
}

\author{
NOOR, H. - MiN, S. ${ }^{*}$ REN, A. X. - LIN, W. - YANG, Z. P. - SHER, A. - GAO, Z.-Q. \\ College of Agriculture, Shanxi Agricultural University, Taigu 030801, Shanxi, PR China \\ *Corresponding author \\ e-mail: sm_sunmin@126.com; phone: +86-354-628-7187; fax: +86-354-628-7187
}

(Received $17^{\text {th }}$ Apr 2020; accepted $14^{\text {th }}$ Aug 2020)

\begin{abstract}
A field experiments was conducted at the Wenxi experimental site of Shanxi Agriculture University, China. A study was designed to evaluate the effect of different planting density and tillage conditions, spike, protein content, protein yield and grain yield of dryland wheat cultivar (Liangxing-99). The five doses of nitrogen application included were the following: $150 \mathrm{~kg} \cdot \mathrm{hm}^{-2}, 225 \mathrm{~kg} \cdot \mathrm{hm}^{-2}, 300 \mathrm{~kg} \cdot \mathrm{hm}^{-}$ ${ }^{2}, 375 \mathrm{~kg} \cdot \mathrm{hm}^{-2}$, and $450 \mathrm{~kg} \cdot \mathrm{hm}^{-2}$. The nitrogen rate/amount has extremely significant effects on the number of ears, thousand-grain weight and yield and water use efficiency of winter wheat. Nitrogen absorption and fertilizer productive efficiency significantly were increase by $50 \%$ and $51 \%$, respectively, while nitrogen harvest index, the number of ears and yield significantly increased by $22 \%, 46 \%$ and the yield by $25 \%, 55 \%$. The water use efficiency significantly increased by $33 \%$. The treatment significantly improved grain albumin $13 \%$, gliadin $14 \%$, gluten protein $17 \%$, total protein $14 \%$, and grain/alcohol ratio $3 \%$; wet gluten content increased by $23 \%$, water absorption by $14 \%$ and, the softening degree was reduced. Improving nitrogen uptake at different growing stages, ultimately increased yield and improved quality. GS activity of flag leaf was closely related with the total grain protein, glutenin, and gliadin content at the middle filling stage. Wide space sowing in Jinnan area was beneficial and increased water consumption during the growth period, also tiller dynamics, promoted nutrient operation, and increased yield and grain protein content.

Keywords: plant height, leaf ratio, protein content, tiller dynamics, water consumption, yield of dryland wheat
\end{abstract}

\section{Introduction}

Wheat (Triticum aestivum L.) is one of the most important food crops in the world and it is also an important food crop in China. Wheat production has an important role in the national economic production of China. Improving yield and quality in production has always been an important task for wheat cultivation workers. The yield and quality of wheat are affected by varieties, environmental factors and cultivation measures (Mao et al., 2015). The arid and semi-arid area of the Loess Plateau is typically rainfed and $60 \%$ of the dryland area is under wheat cultivation (Jin et al., 2007). The cropping system of the Loess Plateau is mainly a mono-cropping of winter wheat with a 3-month fallow during the rainy summer season (Deng et al., 2006). Most studies in the field of water and N (nitrogen) have only focused on soil water and Nitrogen fertilization (Li et al., 2009). High yield of good quality is based on the used agro-technical measures. One of the most important agro-technical measures is optimal nutrient provision. Insufficient precipitation during the growth stages of wheat and shortages of irrigation water in dryland wheat producing areas are major constraints to high yield (Lei et al., 2017). Nitrogen is a nutrient of high importance for plant growth, development and grain quality assurance, but it is also one of the most mobile plant nutrients in the soil 
(Myrbeck et al., 2014). Nitrogen fertilization is a common practice to increase food production, but its performance depends on soil water status (Turner et al., 2005).

Despite many years of research effort there is still no accurate method available for determining how much fertilizer $\mathrm{N}$ can be applied to intensively managed cereal crops to obtain high target yields, maintain adequate soil fertility and minimize environmental risk (Zhu et al., 2006; Robertson et al., 2009). Although emerging evidence indicates that integrated use of manure and chemical Nitrogen fertilizer is a feasible approach to improve winter wheat production and water use efficiency (WUE) in the Loess Plateau (Liu et al., 2012). Winter wheat yield and biomass are dependent on water availability (Kang et al., 2002).

Crop yield and soil nitrate-N residue (NR) have been shown to increase after longterm $\mathrm{N}$ fertilizer application, and at the same time nitrate residue (NR) and its accumulation in soil have been attracting increasing attention. The results from a typical rain fed area of southern Spain showed that the NR in soil increased with time, mostly it accumulated in the 30-60 cm soil layer (López et al., 2013). In a wheat maize system in North China, the NR at harvest was as high as 221-275 $\mathrm{kg} \mathrm{N} \mathrm{ha}^{-1}$ in the $0-90 \mathrm{~cm}$ soil layer and $213-242 \mathrm{~kg} \mathrm{ha}^{-1}$ in the $90-180 \mathrm{~cm}$ soil layer (Ju et al., 2006). Available water and nitrogen are considered the most limiting factors in wheat production in most parts of the world, especially in arid and semi-arid region (Gonzalez et al., 2010).

Therefore, precipitation stored in the soil during the summer fallow period after wheat harvest is utilized by the subsequent crop and crucial for the success of cropping in the Loess Plateau (Zhang et al., 2007; Schlegel et al., 2017).

Water storage in soil has been affected by the different management practices such as tillage and fertilizer application (Grigoras et al., 2012). Winter wheat yield has been increased by the application of fertilizer but it also resulted in increasing soil water depletion and formation of dry subsoil layer especially in the high land areas (Yan et al., 2015). Hence, for sustainable wheat production, it is crucial to seek management practices for improving water-and N-use efficiency (Fu et al., 2014).

Supplemental irrigation and Nitrogen fertilizer application are required to match soil water stress and stabilize yields (Tavakkoli et al., 2004). It was also found that utilization of more nitrogen decreased breaking strength of the second internode significantly (Berry et al., 2000). Reducing spring nitrogen could reduce the height of gravity and increased stem strength by increasing both stem diameter and wall width (Crook et al., 1995). The highest Nitrogen uptake in the growth period occurred from reviving stage to anthesis stage. The proportion of Nitrogen accumulated in leaf and stem was high before the anthesis stage and the accumulated Nitrogen rate in stem reached peak at the anthesis stage (Zhao et al., 2006). Recent technological advances have focused on the simultaneous and synergistic improvement of several factors including water use, nitrogen efficiency, yield and grain quality (Parry et al., 2011).

Nitrogen ( $\mathrm{N}$ ) was a key element for plant nutrition. Applying $\mathrm{N}$ and $\mathrm{P}$ (phosphorus) fertilizers and other management practices increased the yield of wheat but in some cases these show adverse effects due to severely limiting irrigation (El Mejahed and Aouragh, 2005). Nitrogen use efficiency can be increased by combining fertilizer, soil, and water management. Two main approaches can be undertaken: increasing the use of $\mathrm{N}$ during crop growing season and decreasing the losses of $\mathrm{N}$ by applying optimum doses (Cui et al., 2010). At the early filling stage, GS activity of flag leaf was closely related with the total grain protein, glutenin, and gliadin content, while at the middle filling stage, GS activity of flag leaf was closely related with glutenin/gliadin (glu/gli) (Yu et al., 2009). 
The objective of this study were to find the best sowing method and optimize doses of nitrogen level to increase the yield and quality of winter wheat crop. Wide space sowing (WSS) with $300 \mathrm{~kg} \cdot \mathrm{hm}^{-}{ }^{2}$ in Wenxi Shanxi area was beneficial to the growth and development of winter wheat, improved nitrogen uptake at different growing stage, ultimately increased yield and improved quality. The WSS was beneficial and increased water consumption during the growth period, also tiller dynamics, promoted nutrient operation, and increased yield and grain protein content.

\section{Materials and methods}

\section{Description of experimental site}

Field experiment was performed at the Agriculture Research Station of Shanxi Agriculture University $\left(35^{\circ} 200 \mathrm{~N}, 111^{\circ} 170 \mathrm{E}\right)$, in Wenxi county, Shanxi Province of China. The experimental site was located in the southeast of the Loess Plateau. The southeast of the Loess Plateau is a typical semi-arid region with an average annual rainfall of $450-630 \mathrm{~mm}$, of which $60-70 \%$ precipitation falls in July-September, the altitude is $450-700 \mathrm{~m}$ and the annual average temperature is $11-13^{\circ} \mathrm{C}$. This region is characterized by a semiarid climate which receives $491 \mathrm{~mm}$ of average annual precipitation, $12.9^{\circ} \mathrm{C}$ annual mean temperature, and $2242 \mathrm{~h}$ of annual sunshine. The straw was returned to the field after the previous stubble corn was harvested and planted on the 25th October, 2017 and harvested in early June the next year. The soil in the test site adopts the Chinese soil classification standard and belongs to calcareous cinnamon soil. See Table 1 for the soil fertility parameters of the $0-20 \mathrm{~cm}$ soil layer.

Table 1. Soil nutrient properties from experimental location

\begin{tabular}{c|c|c}
\hline Soil nutrients & $\mathbf{2 0 1 6 - 2 0 1 7}$ & $\mathbf{2 0 1 7 - 2 0 1 8}$ \\
\hline Organic matter $\left(\mathrm{g} \mathrm{kg}^{-1}\right)$ & 12.07 & 12.61 \\
Total nitrogen $\left(\mathrm{g} \mathrm{kg}^{-1}\right)$ & 0.86 & 0.88 \\
Alkali-hydrolysis nitrogen $\left(\mathrm{mg} \mathrm{kg}^{-1}\right)$ & 36.42 & 44.07 \\
Available phosphorous $\left(\mathrm{mg} \mathrm{kg}^{-1}\right)$ & 16.26 & 10.71 \\
Available potassium $\left(\mathrm{mg} \mathrm{kg}^{-1}\right)$ & 218.76 & 188.87 \\
\hline
\end{tabular}

\section{Precipitation distribution}

Natural precipitation was the main source of water for crop cultivation in this area, with precipitation mainly concentrating in July-September, which was the fallow period of wheat. Precipitation during experimental years and long-term average of 13 years are given in Table 2. Total precipitation in 2016-2017 was $406.3 \mathrm{~mm}$ during winter wheat growth period and it was $165.4 \mathrm{~mm}$ in the fallow periods. In 2017, precipitation before flowering was more than average in 2017. In 2017-2018, total precipitation was $416.6 \mathrm{~mm}$, and precipitation during growth was $198.3 \mathrm{~mm}$. Precipitation from sowing to wintering and jointing to maturity was abundant. 


$$
-7170 \text { - }
$$

Table 2. Precipitation during study years (2016-2018) and difference in precipitation from average precipitation in the last 13 years (2005-2018) in different growth stages of wheat at the experimental site in Wenxi, China. (Source: Meteorological Observation of Wenxi County, Shanxi Province, China)

\begin{tabular}{c|c|c|c|c|c}
\hline Growth stages & 2005-2016 (means) & $\mathbf{2 0 1 4 - 2 0 1 5}$ & $\mathbf{2 0 1 5 - 2 0 1 6}$ & $\mathbf{2 0 1 6 - 2 0 1 7}$ & $\mathbf{2 0 1 7 - 2 0 1 8}$ \\
\hline S-W & $53.2 \pm 35.9$ & 21.5 & 101.2 & 95.5 & 152.4 \\
W-J & $30.2 \pm 13.6$ & 50.8 & 11.0 & 66.8 & 00 \\
J-A & $37.8 \pm 15.8$ & 61.2 & 57.1 & 27.2 & 49.8 \\
A-M & $64.4 \pm 29.7$ & 17.6 & 122.8 & 51.4 & 16.1 \\
Fallow period & $265.0 \pm 107.5$ & 365.6 & 94.7 & 165.4 & 198.3 \\
Total & $450.5 \pm 96.7$ & 516.7 & 386.8 & 406.3 & 416.6 \\
\hline
\end{tabular}

Fallow period: S-W, W-J, J-A, A-M indicate Jun 20 to Sep 30; S-W (sowing-wintering): Oct 01 to Nov 30: W-J (wintering-jointing): Dec 1 to Apr 10, J-A (jointing-anthesis): Apr 11 to May 11; A-M (anthesismaturity): May 12 to Jun 19, total growth period and total precipitation, respectively

\section{Experimental design and treatments}

The experiment, a typical winter wheat-summer fallow, was started with the winter wheat season, covering 2 successive wheat crops at the same experimental plot. The seeds of winter wheat (Triticum aestivum L.) cultivar 'Liang xing-99' were obtained from Wenxi Agriculture Jinnan. Wheat stubble of $20-30 \mathrm{~cm}$ from the previous wheat crop was left in field to reduce evaporation and to increase organic carbon content in soil. The two factors split-plot design was adopted, with nitrogen rate as the main factor and nitrogen density as sub-plot factor. The sowing methods were wide space sowing (WSS). The details of the machinery and sowing techniques are given in Figure 1 in with five nitrogen level $\left(150 \mathrm{~kg} \cdot \mathrm{hm}^{-2}, 225 \mathrm{~kg} \cdot \mathrm{hm}^{-2}, 300 \mathrm{~kg} \cdot \mathrm{hm}^{-2}, 375 \mathrm{~kg} \cdot \mathrm{hm}^{-2}\right.$, and $\left.450 \mathrm{~kg} \cdot \mathrm{hm}{ }^{-2}\right)$. The plot area was $75 \mathrm{~m}^{2}(2.5 \mathrm{~m} \times 30 \mathrm{~m})$, and it was repeated three times. The straw was returned to the field after the previous stubble corn was harvested and planted on the $25^{\text {th }}$ October, 2017. Before planting, $150 \mathrm{~kg} \cdot \mathrm{N} \cdot \mathrm{hm}^{2}, 150 \mathrm{~kg} \cdot \mathrm{P}_{2} \mathrm{O}_{5} \cdot \mathrm{hm}^{2}{ }^{2}, 90 \mathrm{~kg} \cdot \mathrm{K}_{2} \mathrm{O} \cdot \mathrm{hm}^{2}{ }^{2}$, jointing topdressing $90 \mathrm{~kg} \cdot \mathrm{N} \cdot \mathrm{hm}^{2}{ }^{2}$ were applied, harvested on the $10^{\text {th }}$ June, 2018 (Fig. 2).

\section{Measurement: determination of agronomic traits}

\section{Plant height and leaf area}

Twenty (20) plants with uniform growth and representativeness were taken at each growth stage and the plant height was measured; at the same time the length, width and number of green leaves of the second leaf were measured.

For the determination of leaf area, the length and width of the second leaf and total number of leaves were calculated. Leaf area was measured using the following formula:

$$
\text { Leaf area }=\text { length } \times \text { width } \times \text { number of green leaves } \times 0.85
$$

where 0.85 was the adjustment factor. Then leaf area index (LAI) was calculated by dividing the leaf area $\left(\mathrm{cm}^{2}\right)$ by the ground surface area. 


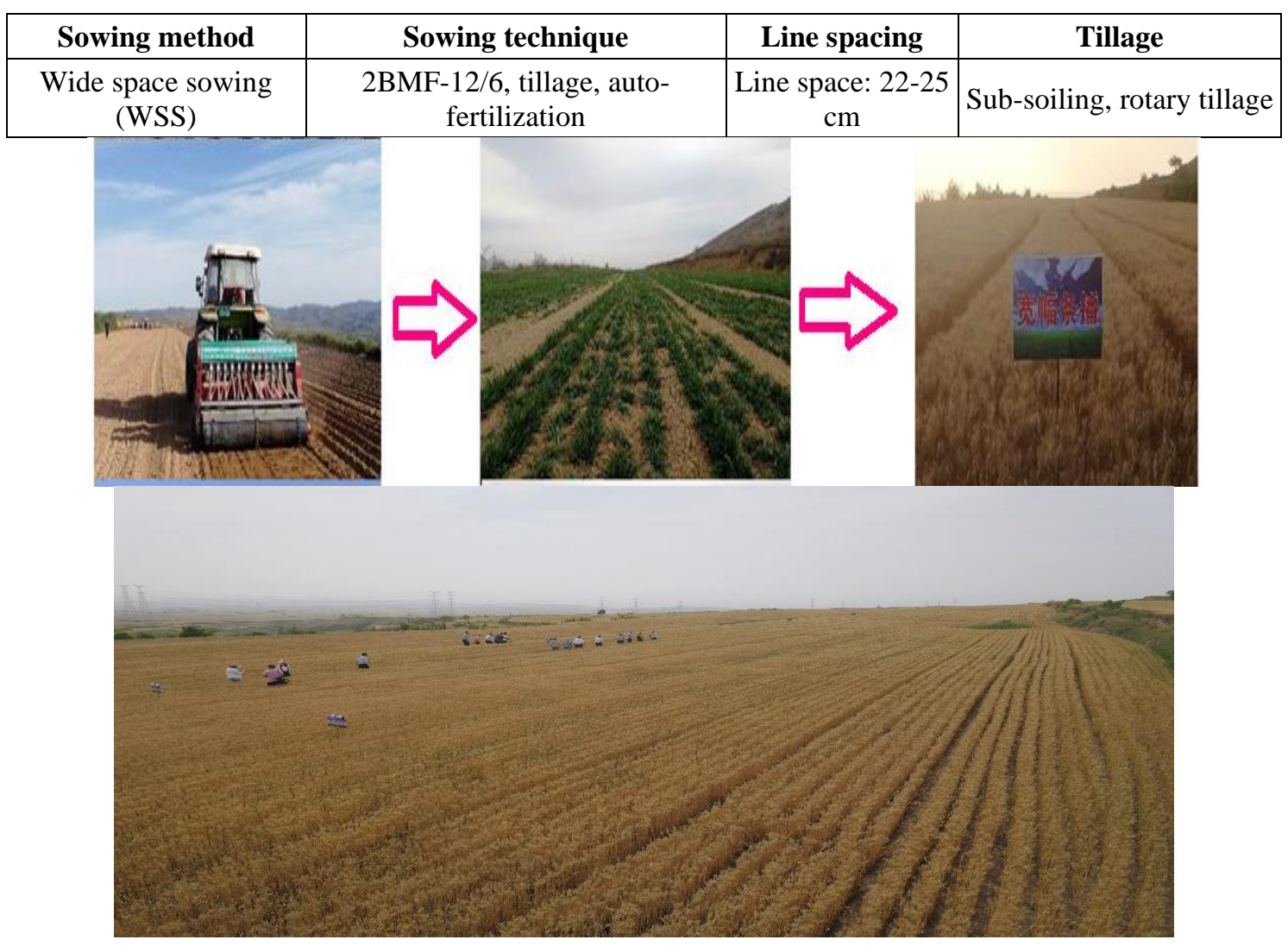

Figure 1. Field preparation at experimental site of Shanxi Agricultural University

\section{Dry matter quality}

Twenty (20) plants with uniform growth and representativeness were taken at each growth stage and placed in an $80{ }^{\circ} \mathrm{C}$ oven for $30 \mathrm{~min}$ and then dried at $80{ }^{\circ} \mathrm{C}$ to constant weight.

\section{Determination and calculation of plant nitrogen content}

After drying and pulverizing each organ of the plants the nitrogen content was measured by $\mathrm{H}_{2} \mathrm{SO}_{4}-\mathrm{H}_{2} \mathrm{O}_{2}$-indigo blue colorimetry. Nitrogen accumulation, running volume and nitrogen efficiency were calculated with reference to Xue et al. (2017). Twenty (20) plants from each plot were collected randomly for the measurement of plant nitrogen concentration at jointing, anthesis and maturity. Plant samples and grains were oven-dried at $105{ }^{\circ} \mathrm{C}$ for $30 \mathrm{~min}$ and then at $75{ }^{\circ} \mathrm{C}$ for $48 \mathrm{~h}$ for dry weight. Dry plant samples were cut to $4-5 \mathrm{~cm}$ length and ground using plant ball mill (FZ102, Beijing, China). Dry grains were also ground to powder using FZ102 mill. Ground samples of $0.25 \mathrm{~g}$ were digested with $\mathrm{H}_{2} \mathrm{SO}_{4}-\mathrm{H}_{2} \mathrm{O}_{2}$, and then total nitrogen concentration was determined using the standard indophenol-blue colorimetric method (Meyer et al., 1983). Calculation of nitrogen accumulation and translation and nitrogen efficiency were carried out as follows (Przurj et al., 2003):

Plant nitrogen accumulation amount $=$ plant dry weight $\times$ plant nitrogen concentration;

Contribution of pre-anthesis organs nitrogen translation amount to grain $=$ preanthesis organs nitrogen translation amount / grain nitrogen accumulation $\times 100 \%$; 
Nitrogen uptake efficiency $\left(\mathrm{kg}^{\prime} \mathrm{kg}^{-1}\right)=$ plant nitrogen accumulation amount / nitrogen fertilizer amount;

Nitrogen use efficiency $\left(\mathrm{kg}^{\prime} \mathrm{kg}^{-1}\right)=$ grain yield / plant nitrogen accumulation amount;

Nitrogen productive efficiency $\left(\mathrm{kg}^{\prime} \mathrm{kg}^{-1}\right)=$ grain yield / nitrogen fertilizer amount.

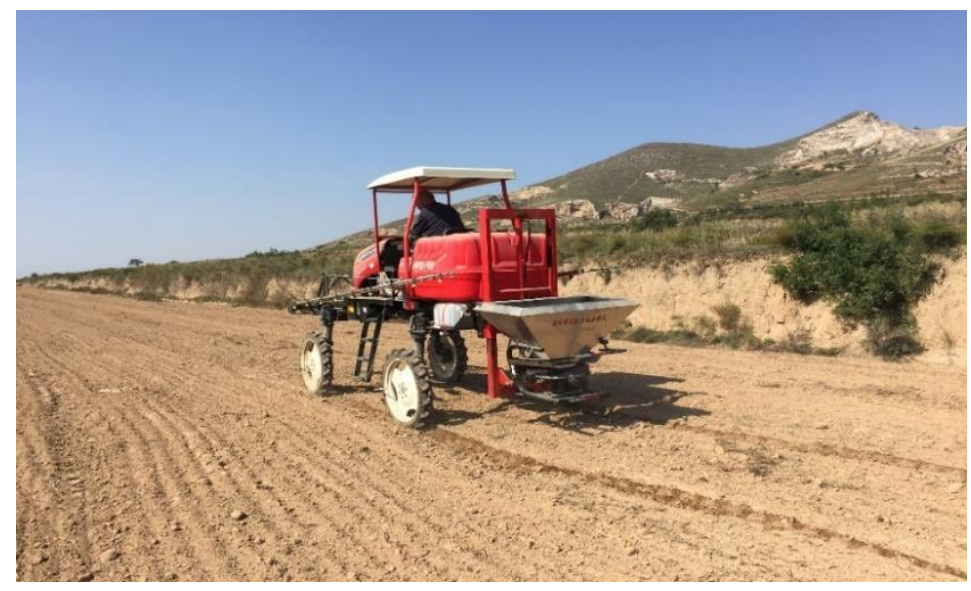

Figure 2. Field preparation use fertilizer machine site of Wenxi

\section{Determination of total tiller and effective tillers rate}

The total number of tillers was investigated at the jointing stage and the number of fertile tillers were counted at late grain filling stage. The number of tillers was calculated from the area of $1 \mathrm{~m}^{2}$ at 3 random points from each plot and average at each plot was the number of stem and tillers. The effective tiller rate was calculated as the proportion of main stem and tiller at jointing stage to the number of effective panicles at maturity.

\section{Grain to leaf area ratio}

Grain to leaf ratio was calculated according to Feng et al. (1999), using Equations 2 and 3:

$$
\begin{aligned}
& \text { Grain number to leaf area ratio }=\frac{\text { total number of grain per unitarea }}{\text { total leaf area on the same plot at booting stage }} \\
& \text { Grain weight to leaf ratio }=\frac{\text { grain weight }(\mathrm{mg}) \text { per unit area }}{\text { total leaf area on the same plotat booting stage }}
\end{aligned}
$$

Total leaf area was taken from the same plot at booting stage $\left(\mathrm{cm}^{2}\right)$.

\section{Determination of soil moisture}

Soil was drilled from 0-300 cm depth with soil drill at sowing, wintering, jointing, flowering and maturity stages. The soil was divided into $20 \mathrm{~cm}$ layers and soil water content and soil water storage were determined.

The soil water storage was calculated by methods as described by He et al. (2009):

$$
\text { SWSi }=\text { Wi } \times \text { Di } \times \text { Hi } \times \frac{10}{100}
$$


where $\mathrm{SWS}_{\mathrm{i}}$ is the soil water storage capacity $(\mathrm{mm})$ of the $\mathrm{i}$-th soil layer; $\mathrm{W}_{\mathrm{i}}$ is the soil water content $(\%)$ of the $\mathrm{i}$-th soil layer; $\mathrm{D}_{\mathrm{i}}$ is the soil bulk density $\left(\mathrm{g} \mathrm{cm}^{-3}\right)$ of the $\mathrm{i}$-th soil layer; $\mathrm{H}_{\mathrm{i}}$ is the thickness of soil layer $(\mathrm{cm})$. The soil water content and soil bulk density were both measured using the oven-drying method Gardner et al. (1986):

\section{Water consumption}

Water consumption in wheat fields was measured using a simplified formula as described by Noor et al. (2020):

$$
E T=P-\Delta S
$$

where $\mathrm{P}$ is the effective precipitation $(\mathrm{mm})$ during that stage and $\Delta \mathrm{S}$ is the reduction of soil water storage at each stage and was measured as $\Delta \mathrm{S}=\mathrm{S}_{1}-\mathrm{S}_{2}$, where $\mathrm{S}_{1}$ and $\mathrm{S}_{2}$ were the soil water content at the beginning and at end of the stage, respectively. Whereas, runoff and drainage were considered negligible.

The water consumption intensity $\left(\mathrm{CWR}, \mathrm{mm} \mathrm{d}^{-1}\right)$ was calculated as:

$$
C w R=\frac{B T_{\bar{i}}}{d}
$$

where ETi is the water consumption (mm) of wheat in each growth stage and $\mathrm{d}$ is the number of days in the growth stage.

\section{Determination of spike number}

Comparison of the spike of interest with the model spike occurs in an n-dimensional vector space, which dimensions are defined by the total spikelet number of the spike of interest. The geometrical difference in GYDAS between the two spikes is based on the scalar product of these two vectors:

$$
\cos x(\vec{a}, \vec{b})=\frac{\vec{a} \cdot \vec{b}}{|\vec{a}| \cdot|\vec{b}|}
$$

\section{Plant density}

Seeds were sown at a density of $225 \times 104 \mathrm{ha}^{-1}$ in rows $20 \mathrm{~cm}$ apart between September 28 and October 30 from 2016 to 2018.

\section{Biomass and yield}

At maturity, the number of panicles per unit area, the average number of grains per panicle and weight of 1000 grains were investigated from 50 plants per plot, and plants from $20 \mathrm{~m}^{2}$ area were harvested to calculate economic yield. For determining the aboveground dry biomass, plant samples were kept at $105^{\circ} \mathrm{C}$ for $30 \mathrm{~min}$, and then oven dried at $75^{\circ} \mathrm{C}$ for $12 \mathrm{~h}$ until constant weight. 


\section{Determination of grain protein and component content}

At maturity period 30 ears were burned at $105^{\circ} \mathrm{C}$ for $30 \mathrm{~min}$, dried at $80{ }^{\circ} \mathrm{C}$ to constant weight, crushed with a DE-100 g mini high-speed universal grinder produced by Zhejiang Hongjingtian Industry and Trade Co., Ltd and a continuous extraction method was used to determine the protein content of the grains.

\section{Determination of kernel quality}

The MJZ-II type gluten index tester was used to determine the wet gluten content and the micro dough LAB 2800 micro flour analyzer was used to determine the flour characteristics.

\section{Statistical analysis}

Data subjected to analysis of variance (ANOVA) and SAS 9.0. Charts were constructed using Microsoft Excel 2007. Mean values were calculated and significance of the difference between treatments was tested by LSD (least significant difference) method at the significance level of $P=0.05$.

\section{Results}

\section{Soil water consumption}

Table 3 shows that with the increase of the seeding amount, the water consumption during the growing period and the proportion of water storage water consumption tend to increase and then decrease. The seeding amount was $300 \mathrm{~kg} \cdot \mathrm{hm}^{-2}$, which is the highest, and the water consumption during the growing period was $369.48 \mathrm{~mm}$. The water consumption ratio of water storage was $40.72 \%$, and the water consumption ratio of precipitation and irrigation water showed a trend of decline and then increased, and reached the lowest value when the seeding amount was $300 \mathrm{~kg} \cdot \mathrm{hm}^{-2}$. It can be seen that the wide sowing amount of $300 \mathrm{~kg} \cdot \mathrm{hm}^{-}{ }^{2}$ was conducive to increasing the water consumption during the growth period and the proportion of stored water consumption, and reducing the proportion of water consumption and irrigation water consumption. The water consumption ratio of precipitation and irrigation water was significantly reduced. Compared with sowing, the water consumption during growing stage and water storage under even sowing the proportion of water increased and the proportion of water consumption in precipitation and irrigation decreased. Wide space sowing and increased the water consumption during the growth period and soil water consumption ratio.

Table 3. Effects of seeding rate on soil water consumption ratio at 0-200 cm depth from different water sources of winter wheat

\begin{tabular}{c|c|c|c|c}
\hline $\begin{array}{c}\text { Seeding rate } \\
\left(\mathbf{k g} \cdot \mathbf{h m}^{-2}\right)\end{array}$ & $\begin{array}{c}\text { Soil water consumption in the } \\
\text { growing stage }(\mathbf{m m})\end{array}$ & $\begin{array}{c}\text { Soil water consumption } \\
\text { ratio }(\%)\end{array}$ & $\begin{array}{c}\text { Precipitation } \\
\text { consumption ratio }(\%)\end{array}$ & $\begin{array}{c}\text { Irrigation consumption } \\
\text { ratio }(\%)\end{array}$ \\
\hline 150 & $447.71^{\mathrm{c}}$ & $37.84^{\mathrm{c}}$ & $48.76^{\mathrm{a}}$ & $13.40^{\mathrm{a}}$ \\
225 & $451.13^{\mathrm{b}}$ & $38.31^{\mathrm{c}}$ & $48.39^{\mathrm{a}}$ & $13.30^{\mathrm{a}}$ \\
300 & $469.48^{\mathrm{a}}$ & $40.72^{\mathrm{a}}$ & $46.50^{\mathrm{c}}$ & $12.78^{\mathrm{c}}$ \\
375 & $459.96^{\mathrm{b}}$ & $39.49^{\mathrm{b}}$ & $47.46^{\mathrm{b}}$ & $13.04^{\mathrm{b}}$ \\
450 & $447.68^{\mathrm{c}}$ & $37.83^{\mathrm{c}}$ & $48.76^{\mathrm{a}}$ & $13.40^{\mathrm{a}}$ \\
\hline
\end{tabular}




\section{Effects of seeding rate on soil water consumption plant height and leaf area of dryland wheat}

The effects of nitrogen rate on soil water consumption on plant height and leaf area of winter wheat from 2016 to 2017 were as follows, the plant height was significantly the highest when the sowing amount was $375 \mathrm{~kg} \cdot \mathrm{hm}^{-2}$ in the wintering period from 2017 to 2018, the plant height was significantly the highest when the sowing amount was 450 $\mathrm{kg} \cdot \mathrm{hm}^{-2}$ in the wintering period; in the two years, when the sowing amount was $300 \mathrm{~kg} \cdot \mathrm{hm}^{-}$ ${ }^{2}$, the plant height was significantly the highest from the elongation stage to the maturity stage and the plant height was significantly the lowest when the sowing amount was 150 $\mathrm{kg} \cdot \mathrm{hm}^{-2}$ (Fig. 3). In those two years, when the sowing amount was $300 \mathrm{~kg} \cdot \mathrm{hm}^{-2}$ the leaf area was significantly the highest in each growth period and the leaf area was significantly the lowest when the sowing amount was $150 \mathrm{~kg} \cdot \mathrm{hm}^{-2}$. It can be seen that the increase of sowing volume $\left(150-300 \mathrm{~kg} \cdot \mathrm{hm}^{-2}\right)$ was beneficial to the increase of plant height and leaf area of wheat.
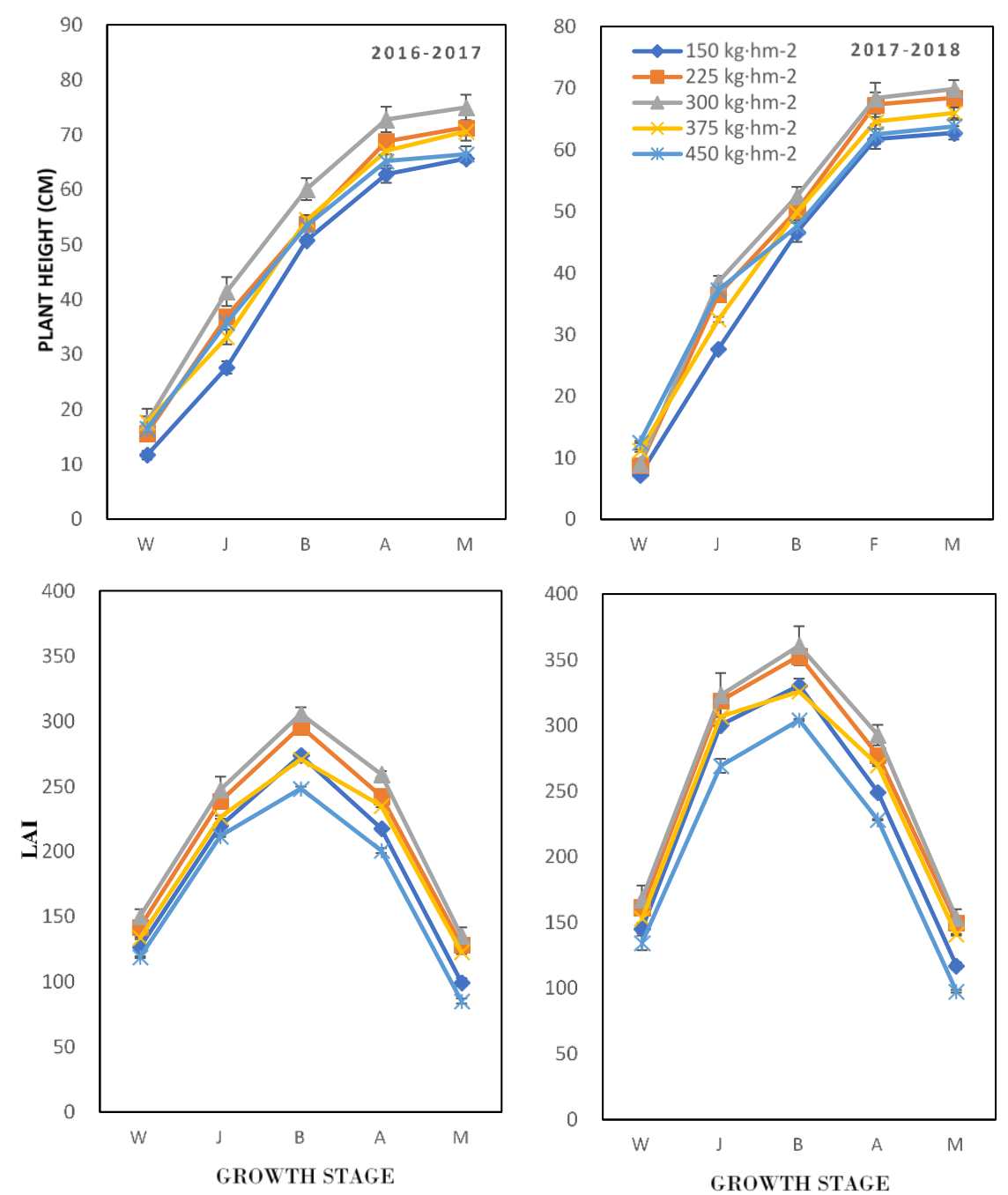

Figure 3. Effects of seeding rate on plant height and leaf area index (LAI) at different growth stages of dryland wheat. $W, J, B, F, A$, and $M$ indicate Wintering, Jointing, Booting, Flowering, Anthesis and maturity W-J: Wintering to jointing, Oct 1 to Apr 10; J-B: Jointing to Booting, Apr 11 to May 10; B-F: Booting to Flowering, May 11 to May 25 B-A: Booting stage to anthesis, May 26 to Jun 10; A-M: Anthesis to maturity, Jun 12 to Jun 19 


\section{Effects of seeding rate on soil water consumption amount and on population dynamics of WSS dryland wheat}

Effects of nitrogen rate on soil water consumption in wintering stage examined throughout two years can be seen in Figure 4. Group with $375 \mathrm{~kg} \cdot \mathrm{hm}^{-2}$ sowing amount showed the highest tailoring and had a significant jointing stage, mature stage and sowing quantity. Group $300 \mathrm{~kg} \cdot \mathrm{hm}^{-2}$ showed the highest tiller number in the growth period (2016 to 2017), and the flowering period and mature period reached significant level (2017 to 2018), the sowing quantity of different levels the nitrogen level of $150 \mathrm{~kg} \cdot \mathrm{hm}^{-2}$ tiller number was lowest significantly. Lower sowing quantity of the wide space sowing (WSS) was $300 \mathrm{~kg} \cdot \mathrm{hm}^{-2}$, which was conducive to the formation of tiller number and yield.
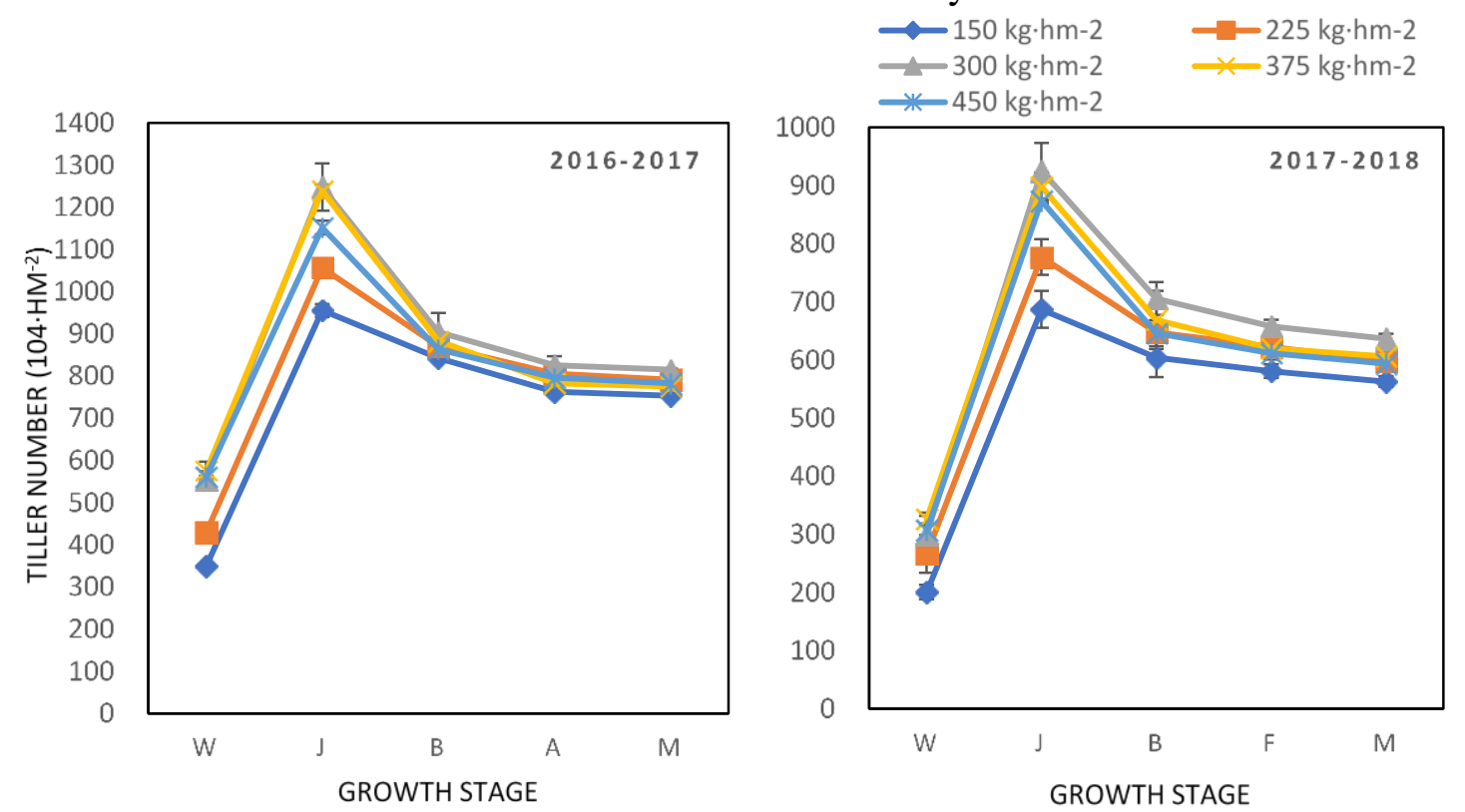

Figure 4. Effects of seeding rates on water consumption of tiller dynamics at different growth stages of dryland wheat. $W, J, B, F, A$, and $M$ indicate Wintering, Jointing, Booting, Flowering, Anthesis and maturity W-J: Wintering to jointing, Oct 1 to Apr 10; J-B: Jointing to Booting, Apr 11 to May 10; B-F: Booting to Flowering, May 11 to May 25 B-A. Booting stage to anthesis, May 26 to Jun 10; A-M: Anthesis to maturity, Jun 12 to Jun 19. Different letters indicate significant difference among treatments at the significance level of $p \leq 0.05$

\section{Effects of seeding rate on dry matter accumulation characteristics of winter wheat}

Effects of nitrogen rate on dry matter accumulation characteristics are shown in Table 4. The results show that with the increase of sowing amount the dry matter mass of the plants increased first and then decreased in each growth period and the highest sowing amount was $300 \mathrm{~kg} \cdot \mathrm{hm}^{-2}$. During the wintering period and booting period the dry matter quality of the plants was the highest when the sowing amount was $300 \mathrm{~kg} \cdot \mathrm{hm}^{-2}$, but there was no significant difference from $225 \mathrm{~kg} \cdot \mathrm{hm}^{-2}$, when the sowing amount was $450 \mathrm{~kg} \cdot \mathrm{hm}^{-}$ 2 . During the flowering period and maturity period the dry matter quality of the plants was the highest significantly when the sowing amount was $300 \mathrm{~kg} \cdot \mathrm{hm}^{-2}$ and the difference was not significant when the sowing amount was $225 \mathrm{~kg} \cdot \mathrm{hm}^{-2}$. It can be seen in Table 4, that it is beneficial to improve the dry matter quality of the plants especially in the late growth period, when the down sowing quantity of the WSS is $300 \mathrm{~kg} \cdot \mathrm{hm}^{-2}$. 


$$
-7177-
$$

Table 4. Effects of seeding rate on dry weight at different growth stages $\left(\mathrm{kg} \cdot \mathrm{hm}^{-2}\right)$

\begin{tabular}{c|c|c|c|c|c}
\hline $\begin{array}{c}\text { Seeding rate } \\
\left(\mathbf{k g} \cdot \mathbf{h m}^{-2}\right)\end{array}$ & Wintering & Jointing & Booting & Anthesis & Maturity \\
\hline 150 & $3605.25^{\mathrm{b}}$ & $4624.41^{\mathrm{d}}$ & $7487.85^{\mathrm{c}}$ & $9397.70^{\mathrm{d}}$ & $11304.81^{\mathrm{c}}$ \\
225 & $3786.32^{\mathrm{ab}}$ & $4906.33^{\mathrm{bc}}$ & $8506.25^{\mathrm{b}}$ & $10727.24^{\mathrm{b}}$ & $13759.48^{\mathrm{b}}$ \\
300 & $4022.77^{\mathrm{a}}$ & $5213.31^{\mathrm{a}}$ & $9246.29^{\mathrm{a}}$ & $11429.16^{\mathrm{a}}$ & $14589.44^{\mathrm{a}}$ \\
375 & $3804.43^{\mathrm{ab}}$ & $5054.21^{\mathrm{ab}}$ & $8642.98^{\mathrm{ab}}$ & $10890.31^{\mathrm{b}}$ & $13657.66^{\mathrm{b}}$ \\
450 & $3729.79^{\mathrm{b}}$ & $4785.13^{\mathrm{cd}}$ & $8104.08^{\mathrm{bc}}$ & $9886.77^{\mathrm{c}}$ & $11250.73^{\mathrm{c}}$ \\
\hline
\end{tabular}

\section{Effects on agronomic characters at maturity stage}

Agronomic characters (Table 5) show that the Nitrogen rate was $300 \mathrm{~kg} \cdot \mathrm{hm}^{-2}$, with the longest ear length $(7.51 \mathrm{~cm})$, which was not significantly different from $375 \mathrm{~kg} \cdot \mathrm{hm}^{-2}$. The number of pregnable spikelet was the highest (13.87), and the number of non-pregnable spikelet was the lowest (1.17). The number of pregnable spikelets can be increased and the number of non-pregnable spikelets can be reduced when the wide space sowing amount is $300 \mathrm{~kg} \cdot \mathrm{hm}^{-2}$, which is ultimately beneficial to the formation of yield.

Table 5. Effects of seeding rate on agronomic characters at maturity

\begin{tabular}{c|c|c|c}
\hline $\begin{array}{c}\text { Seeding rate } \\
\left(\mathbf{k g} \cdot \mathbf{h m}^{-2}\right)\end{array}$ & Spike length (cm) & Bearing spikelet number & $\begin{array}{c}\text { Sterility spikelet } \\
\text { number }\end{array}$ \\
\hline 150 & $7.20^{\mathrm{b}}$ & $13.17^{\mathrm{b}}$ & $1.87^{\mathrm{bc}}$ \\
225 & $7.21^{\mathrm{b}}$ & $13.30^{\mathrm{b}}$ & $1.72^{\mathrm{c}}$ \\
300 & $7.51^{\mathrm{a}}$ & $13.87^{\mathrm{a}}$ & $1.17^{\mathrm{d}}$ \\
375 & $7.32^{\mathrm{ab}}$ & $12.20^{\mathrm{c}}$ & $2.17^{\mathrm{b}}$ \\
450 & $6.15^{\mathrm{c}}$ & $10.43^{\mathrm{d}}$ & $2.80^{\mathrm{a}}$ \\
\hline
\end{tabular}

\section{Effects of seeding rate on nitrogen uptake at different growing stages}

The effect of seeding rate on nitrogen uptake at different growing stages of winter wheat is presented in Table 6. The results show that with the increase of sowing amount the nitrogen accumulation of plants in each growth period showed a trend of increasing first and then decreased and reached the maximum at $300 \mathrm{~kg} \cdot \mathrm{hm}^{-2}$ and it was also observed that with the increase of sowing amount the contribution rates of nitrogen accumulation before flowering and nitrogen accumulation before flowering on grains increased first and then decreased reaching the highest at $300 \mathrm{~kg} \cdot \mathrm{hm}^{-2}$ and the nitrogen accumulation after flowering and nitrogen accumulation after flowering had no significant effect on the contribution rates of grains.

Table 6. Effects of seeding rate on nitrogen uptake at different growing stage

\begin{tabular}{c|c|c|c|c|c}
\hline Seeding rate $\left.\mathbf{( k g} \cdot \mathbf{h m}^{-2}\right)$ & Wintering & Jointing & Booting & Flowering & Maturity \\
\hline 150 & $30.17^{\mathrm{d}}$ & $39.29^{\mathrm{e}}$ & $85.65^{\mathrm{e}}$ & $104.06^{\mathrm{e}}$ & $132.00^{\mathrm{e}}$ \\
225 & $35.21^{\mathrm{c}}$ & $48.10^{\mathrm{c}}$ & $116.53^{\mathrm{c}}$ & $129.25^{\mathrm{c}}$ & $160.50^{\mathrm{c}}$ \\
300 & $40.21^{\mathrm{a}}$ & $54.05^{\mathrm{a}}$ & $124.14^{\mathrm{a}}$ & $143.38^{\mathrm{a}}$ & $171.00^{\mathrm{a}}$ \\
375 & $37.65^{\mathrm{b}}$ & $51.39^{\mathrm{b}}$ & $118.79^{\mathrm{b}}$ & $136.11^{\mathrm{b}}$ & $165.00^{\mathrm{b}}$ \\
450 & $29.66^{\mathrm{d}}$ & $40.94^{\mathrm{d}}$ & $102.21^{\mathrm{d}}$ & $110.78^{\mathrm{d}}$ & $141.00^{\mathrm{d}}$ \\
\hline
\end{tabular}




\section{Effects of seeding rate on pre-anthesis accumulated nitrogen translocation and nitrogen accumulation amount after anthesis of winter wheat}

Effects of seeding rate on pre-anthesis accumulated nitrogen translocation and nitrogen accumulation amount are presented in Table 7. With the increase of sowing amount, the accumulation of nitrogen in each growth stage showed a trend of first increasing and then decreasing, reaching the highest at $300 \mathrm{~kg} \cdot \mathrm{hm}^{-2}$. The sowing methods mainly promote the operation of nitrogen accumulation before flowering to increase the contribution rate to grains, among which WSS was better.

Table 7. Effects of seeding rate on pre-anthesis accumulated nitrogen translocation and nitrogen accumulation amount after anthesis of winter wheat

\begin{tabular}{|c|c|c|c|c|}
\hline \multirow{2}{*}{$\begin{array}{l}\text { Seeding rate } \\
\left(\mathrm{kg} \cdot \mathbf{h m}^{-2}\right)\end{array}$} & \multicolumn{3}{|c|}{ PANT } & \multirow{2}{*}{$\begin{array}{c}\text { NAAA } \\
\text { CN in grains }(\%)\end{array}$} \\
\hline & TA $\left(\mathbf{k g} \cdot \mathbf{h m}^{-2}\right)$ & $\mathrm{CN}$ in grains $(\%)$ & TA $\left(\mathrm{kg} \cdot \mathrm{hm}^{-2}\right)$ & \\
\hline 150 & $81.96^{c}$ & $74.58^{\mathrm{b}}$ & $27.94^{\mathrm{b}}$ & $25.42^{\mathrm{ab}}$ \\
\hline 225 & $101.53^{b}$ & $76.46 \mathrm{a}^{\mathrm{b}}$ & $31.25^{\mathrm{a}}$ & $23.54^{\mathrm{ab}}$ \\
\hline 300 & $112.14^{\mathrm{a}}$ & $80.24^{\mathrm{a}}$ & $27.62^{b}$ & $19.76^{\mathrm{b}}$ \\
\hline 375 & $106.04^{b}$ & $78.59^{\mathrm{ab}}$ & $28.89^{\mathrm{ab}}$ & $21.41^{\mathrm{ab}}$ \\
\hline 450 & $85.93^{c}$ & $73.98^{\mathrm{b}}$ & $30.22^{\mathrm{ab}}$ & $26.02^{\mathrm{a}}$ \\
\hline
\end{tabular}

PANT: Pre-anthesis accumulated nitrogen translocation amount from vegetative organs to grains after anthesis; NAAA: Nitrogen accumulation amount after anthesis; TA: Translation amount; $\mathrm{CN}$ : Contribution nitrogen

\section{Effects of seeding rate on nitrogen use efficiency (NUE) of winter wheat}

The nitrogen use efficiency (Table 8) shows that with the increase of sowing amount the nitrogen absorption efficiency and nitrogen fertilizer production efficiency first increased and then decreased and reached the highest at $300 \mathrm{~kg} \cdot \mathrm{hm}^{-2}$, while the nitrogen utilization efficiency first decreased and then increased with no significant effect on the nitrogen harvest index. It can be seen that when the lower sowing amount was $300 \mathrm{~kg} \cdot \mathrm{hm}^{-}$ ${ }^{2}$ (WSS), it was beneficial and the accumulation of nitrogen in each growth period increased along with the contribution rate of nitrogen running amount with grains before flowering and the nitrogen absorption efficiency and nitrogen fertilizer production efficiency improved.

Table 8. Effects of seeding rate on nitrogen use efficiency (NUE) of dryland wheat

\begin{tabular}{|c|c|c|c|c|}
\hline $\begin{array}{c}\text { Seeding rate } \\
\left(\mathbf{k g} \cdot \mathbf{h m}^{-2}\right)\end{array}$ & $\begin{array}{c}\text { N uptake efficiency } \\
\left(\mathrm{kg} \cdot \mathrm{kg}^{-1}\right)\end{array}$ & $\begin{array}{c}\text { N use efficiency } \\
\left(\mathrm{kg} \cdot \mathrm{kg}^{-1}\right)\end{array}$ & $\begin{array}{c}\text { N productive efficiency } \\
\left(\mathrm{kg}^{\prime} \cdot \mathrm{kg}^{-1}\right)\end{array}$ & $\begin{array}{c}\text { Nitrogen } \\
\text { harvest index }\end{array}$ \\
\hline 150 & $0.88^{\mathrm{d}}$ & $45.44^{\mathrm{a}}$ & $39.98^{c}$ & $0.83^{\mathrm{a}}$ \\
\hline 225 & $1.07^{\mathrm{b}}$ & $40.14^{\mathrm{d}}$ & $42.95^{b}$ & $0.83^{\mathrm{a}}$ \\
\hline 300 & $1.14^{\mathrm{a}}$ & $41.86^{\mathrm{c}}$ & $47.72^{\mathrm{a}}$ & $0.82^{\mathrm{b}}$ \\
\hline 375 & $1.10^{\mathrm{ab}}$ & $41.85^{\mathrm{c}}$ & $46.04^{\mathrm{a}}$ & $0.82^{\mathrm{ab}}$ \\
\hline 450 & $0.94^{\mathrm{c}}$ & $43.98^{b}$ & $41.34^{\mathrm{bc}}$ & $0.82^{\mathrm{ab}}$ \\
\hline
\end{tabular}

\section{Effects of seeding rate yield and composition of dryland wheat}

The effects of seeding rate yield and composition are presented in Table 9. The results show that with the increase of sowing amount, the panicle-number and yield show a trend 
of increasing first and then decreasing. When the sowing amount is $300 \mathrm{~kg} \cdot \mathrm{hm}^{-2}$, the panel-number is the highest significantly, reaching $636.00 \times 104 \cdot \mathrm{hm}^{-2}$ and the highest yield is $7158.30 \mathrm{~kg} \cdot \mathrm{hm}^{-2}$, but there is no significant difference from $375 \mathrm{~kg} \cdot \mathrm{hm}^{-2}$. The number of panicle grains was the highest when the sowing amount was $300 \mathrm{~kg} \cdot \mathrm{hm}^{-2}$, but there was no significant difference from $150 \mathrm{~kg} \cdot \mathrm{hm}^{-2}$ and $375 \mathrm{~kg} \cdot \mathrm{hm}^{-2}$. The difference of 1000 -grain weight in the range of $300-450 \mathrm{~kg} \cdot \mathrm{hm}^{-2}$ was not significant. It can be seen that the appropriate sowing amount is the key to increase the wheat yield, and the excessive or low sowing amount is not conducive to the formation of yield, and the number of ears is the key factor affecting the formation of yield. The appropriate sowing amount under wide space sowing is $300 \mathrm{~kg} \cdot \mathrm{hm}^{-2}$.

Table 9. Effects of seeding rate and $N$ input on yield components of dryland wheat

\begin{tabular}{|c|c|c|c|c|}
\hline $\begin{array}{c}\text { Seeding rate } \\
\left(\mathbf{k g} \cdot \mathbf{h m}^{-2}\right)\end{array}$ & $\begin{array}{c}\text { Ear number } \\
\left(10^{4} \cdot \mathbf{h m}^{-2}\right)\end{array}$ & $\begin{array}{c}\text { Grain number per } \\
\text { spike }\end{array}$ & $\begin{array}{c}\text { 1000-grain weight } \\
\text { (g) }\end{array}$ & $\begin{array}{c}\text { Yield } \\
\left(\mathbf{k g} \cdot \mathbf{h m}^{-2}\right)\end{array}$ \\
\hline 150 & $562.33^{\mathrm{c}}$ & $32.95^{\mathrm{ab}}$ & $39.12^{c}$ & $5997.57^{\mathrm{c}}$ \\
\hline 225 & $597.67^{\mathrm{b}}$ & $31.99^{b}$ & $39.90^{b c}$ & $6442.10^{b}$ \\
\hline 300 & $636.00^{\mathrm{a}}$ & $33.85^{\mathrm{a}}$ & $41.20^{\mathrm{a}}$ & $7158.30^{\mathrm{a}}$ \\
\hline 375 & $605.33^{\mathrm{b}}$ & $32.72^{a b}$ & $41.06^{\mathrm{a}}$ & $6905.33^{a}$ \\
\hline 450 & $593.33^{\mathrm{b}}$ & $29.50^{c}$ & $40.68^{\mathrm{ab}}$ & $6201.40^{b c}$ \\
\hline
\end{tabular}

\section{Effects of seeding rate on protein and component contents of mature grains}

The protein and component contents of mature grains are presented in Table 10. The results show that with the increase of sowing amount the contents of grain protein components and protein yield first increased and then decreased. The yield of grain albumin, globulin and protein was significantly the highest when the sowing volume was $300 \mathrm{~kg} \cdot \mathrm{hm}^{-2}$ and the content of altoprotein, glutenin, grain/alcohol ratio and protein was the highest but there was no significant difference from that of $225 \mathrm{~kg} \cdot \mathrm{hm}^{-2}$. It can be seen that the seed size of $300 \mathrm{~kg} \cdot \mathrm{hm}^{-2}$ was beneficial and increased the content of protein and components in grains.

Table 10. The protein components and protein yield of wheat under different nitrogen rate

\begin{tabular}{c|c|c|c|c|c|c|c}
\hline $\begin{array}{c}\text { Seeding rate } \\
\left(\mathbf{k g} \cdot \mathbf{h m}^{-2}\right)\end{array}$ & $\begin{array}{c}\text { Albumin } \\
(\boldsymbol{\%})\end{array}$ & $\begin{array}{c}\text { Globulin } \\
(\boldsymbol{\%})\end{array}$ & $\begin{array}{c}\text { Gliadin } \\
(\boldsymbol{\%})\end{array}$ & $\begin{array}{c}\text { Glutenin } \\
(\boldsymbol{\%})\end{array}$ & Glu/Gli & $\begin{array}{c}\text { Protein content } \\
(\boldsymbol{\%})\end{array}$ & $\begin{array}{c}\text { Protein yield } \\
\left(\mathbf{k g} \cdot \mathbf{h m}^{-2}\right)\end{array}$ \\
\hline 150 & $2.44^{\mathrm{b}}$ & $1.57^{\mathrm{b}}$ & $4.29^{\mathrm{b}}$ & $4.28^{\mathrm{c}}$ & $1.00^{\mathrm{b}}$ & $13.80^{\mathrm{c}}$ & $827.56^{\mathrm{c}}$ \\
225 & $2.53^{\mathrm{b}}$ & $1.62^{\mathrm{b}}$ & $4.36^{\mathrm{a}}$ & $4.51^{\mathrm{a}}$ & $1.03^{\mathrm{a}}$ & $14.66^{\mathrm{a}}$ & $944.13^{\mathrm{b}}$ \\
300 & $2.74^{\mathrm{a}}$ & $1.81^{\mathrm{a}}$ & $4.40^{\mathrm{a}}$ & $4.59^{\mathrm{a}}$ & $1.04^{\mathrm{a}}$ & $15.04^{\mathrm{a}}$ & $1076.81^{\mathrm{a}}$ \\
375 & $2.50^{\mathrm{b}}$ & $1.61^{\mathrm{b}}$ & $4.23^{\mathrm{c}}$ & $4.37^{\mathrm{b}}$ & $1.03^{\mathrm{a}}$ & $14.22^{\mathrm{b}}$ & $982.16^{\mathrm{b}}$ \\
450 & $2.28^{\mathrm{c}}$ & $1.31^{\mathrm{c}}$ & $3.91^{\mathrm{d}}$ & $3.90^{\mathrm{d}}$ & $1.00^{\mathrm{b}}$ & $13.26^{\mathrm{d}}$ & $822.40 \mathrm{c}$ \\
\hline
\end{tabular}

\section{Correlation analysis of water consumption from soil at different growth stages and yield and yield related components of wheat}

Correlation coefficients of water and plant nitrogen accumulation with yield and quality traits are presented in Table 11. The results show that water consumption during growth period showed a significant or extremely significant positive correlation with the 
amount of nitrogen accumulated before flowering yield panicle number, 1000-grain weight, protein content and grain/alcohol ratio. The yield was positively correlated with panicle number and positively correlated with panicle grain number and 1000-grain weight. The protein content was positively correlated with the amount of nitrogen accumulated before flowering and the grain/alcohol ratio.

Table 11. The correlation index between grain yield and quality traits in different seeding rate

\begin{tabular}{c|c|c|c}
\hline Grain yield quality & $\begin{array}{c}\text { Soil water consumption in the } \\
\text { growing stage }\end{array}$ & Yield & $\begin{array}{c}\text { Protein } \\
\text { content }\end{array}$ \\
\hline PANT amount & $0.8887^{* *}$ & $0.9580^{* *}$ & $0.8610^{*}$ \\
Yield & $0.9640^{* *}$ & - & - \\
Ear number & $0.8850^{* *}$ & $0.9236^{* *}$ & - \\
Grain number per spike & 0.6676 & $0.8447^{*}$ & - \\
1000-grain weight & $0.7299^{*}$ & $0.8200^{*}$ & - \\
Protein content & $0.9640^{* *}$ & - & - \\
Glu/Gli & $0.8013^{*}$ & - & $0.9246^{* *}$ \\
\hline
\end{tabular}

*Significant at 0.05 level. **Significant at 0.01 level

\section{Discussion}

Wheat production in Hugong Township, Wenxi region are facing great challenges due to scant water supply and nutrient deficit. Due to the sparse and deep groundwater resources, rainfall is the sole water source for wheat production in the Loess Plateau, which is limited $(200-600 \mathrm{~mm})$ and unevenly distributed. $30 \%-40 \%$ of annual rainfall occurs during winter wheat growing season, whereas most of the rain falls between July and September, which is concurrent with the summer fallow between two growing seasons of winter wheat (Li et al., 2015). Water stress is the main limiting factor for wheat production in Loess Plateau and other arid and semiarid regions (Liu et al., 2007). The growth of winter wheat plants depends on the soil water stored by rainfall during summer fallow season (60-70\%) and growing season (30-40\%). The roots of rain fed winter wheat are not able to utilize water from deeper soil layers and ground water (Li et al., 2017). Hence, the limiting precipitation during growth season means that winter wheat must utilize soil water stored from precipitation during fallow season (Xue et al., 2019).

\section{Effect of seeding rate on Soil water consumption}

In addition, nitrogen also significantly affects crop yield under water deficient conditions. Winter wheat under water deficient conditions, supplying post-anthesis nitrogen fertilizer increases grain yield by decreasing the sink limitation and not by increasing source strength (Madani et al., 2010). Therefore, nitrogen fertilizer has no relation with sesame phonological traits under higher rainfall areas, whereas in droughtprone areas, zero fertilization might flower earlier than the fertilized one. Taller plants $(116 \mathrm{~cm})$, higher LAI (0.78), higher branches per plant (8.7), and TDM per plant $(32.7 \mathrm{~g})$ were obtained with the application of $100 \mathrm{~kg} \cdot \mathrm{N} / \mathrm{ha}$ in Nigeria (Haruna et al., 2011). Nitrogen could influence leaf area, active life span, chlorophyll content, tuber size and tuber bulking time to affect yield (Goffart et al., 2008). The use of wide range precision sowing method under the condition of corn straw mulch significantly improved water use 
efficiency and reduced water consumption (Liu et al., 2015). The soil water storage capacity of 0-300 $\mathrm{cm}$ soil layer with full membrane soil hole sowing increased during sowing jointing and grouting and the water consumption intensity increased during sowing jointing water use efficiency increased. (Hou et al., 2017). Compared with conventional sowing, the total water consumption under wide space sowing increased and water use efficiency increased ( $\mathrm{Li}$ et al., 2015). The yield and yield parameters were significantly affected due to application of nitrogen and irrigation water. For higher yield, it is better to apply nitrogen at the stem elongation and heading unless it is not irrigated with minimum amount of water (Cao et al., 2008a).

The effect is better and the percentage of soil water consumption in the $0-200 \mathrm{~cm}$ soil layer under wide space sowing is significantly higher than in other sowing methods and the water consumption during the growth period and water use efficiency under (WSS) are increased. The increase of $17 \%$ and $33 \%$ may be due to the uneven distribution of the roots in the upper layer of conventional seeding which caused the root density between individual plants to be much lower than the density of the roots in the row. This caused the soil moisture to be lost in the manner of soil evaporation. The individual growth and nutrient movement of wheat during the whole growth period has a very important influence on the formation of grain yield (Chu et al., 2018), there was a significant negative correlation between nitrogen accumulation and nitrogen use efficiency and a significant positive correlation between nitrogen absorption efficiency and nitrogen use efficiency. This study shows that wide space sowing can significantly increase plant nitrogen accumulation at various growth stages and the contribution rate to grains is mainly increased by the amount of nitrogen before flowering, which is consistent with previous research results (Xue et al., 2017). Nitrogen absorption efficiency, nitrogen fertilizer production efficiency and nitrogen harvest index significantly improved, but the mechanism that affects nitrogen operation by wide space sowing needs further study. The number of spike grains per spike and thousand grain weight are the elements of yield formation. Dang et al., 2015 showed that compared with the traditional sowing method, the use of wide precision sowing increased the number of ears by $5 \%$, the number of ears by $5 \%$, the weight per thousand by $3 \%$, and the yield increased by $12 \%$. The number of ears and yield showed a very significant positive correlation. There was a significant positive correlation between ear number and thousand-grain weight and yield. It can be seen that wide space sowing (WSS) mainly increased yield by increasing ear number which is the same as that of ( $\mathrm{Li}$ et al., 2012). The yield is significantly positively related to the water consumption during the growth period and the nitrogen accumulation before flowering. Wide space sowing has high water consumption during the growth period and high nitrogen before bloom which promotes nutrient absorption and operation and increases yield. In addition the broad soiled sowing population structure is reasonable, significantly increasing the number of tillers in the middle and late stages of reproductive growth, along with ear length, and the number of fertile spikelet's, while it significantly reduces the number of infertile spikelet's, increases the leaf area in the later stages of growth and increases growth stages. The accumulation of dry matter is conducive to the increase of yield.

\section{Effect of seeding rate on the regulation of quality}

The technical quality of wheat is a very complex character, applied technologies and agro-ecological conditions. The high content of mineral nutrition, especially nitrogen, affects the quality of the process. These results showed that higher $\mathrm{N}$ rate has a positive 
effect on wheat grain quality. Higher density provides a greater number of primary tillers per square meter, which causes the formation of grains with larger size and mass. These grains have a more favorable ratio of storage proteins and starch, which requires better quality. In crops with a lower density, a greater number of secondary tillers are created, which produce small grains with less weight and lower quality. These results agree with those of Geleta et al. (2002). From our results, we conclude that the application of slurry had small but significant influences on yield and quality compared to mineral fertilization. This effect was also found by Sieling et al. (1997).

Quality parameters investigated in this paper significantly depended on applied nitrogen doses. The application of an increased nitrogen fertilization dose caused an increase of quality traits. The highest increase of sedimentation value and wet gluten content established in $\mathrm{N} 3$ variant when applied $120 \mathrm{~kg} \mathrm{ha}^{-1}$ of nitrogen, which agree with our previous results (Zecevic et al., 2005). By analysis of variance, it was established that both of the analyzed quality traits significantly depended on genotypes and investigated years. Interactions between genotypes, applied nitrogen doses and years were also highly significant, which means that new genotypes positively reacted to nitrogen application (Guarda et al., 2004). Research showed that the use of wide stubble sowing can make wheat individuals grow robustly which can significantly increase the bulk density and hardness of wheat grains, significantly improve water absorption wet gluten content and sedimentation value and significantly increase the maximum resistance of dough, the standard value of power and flour quality, but has no significant effect on flour protein content and dough ductility (Wang et al., 2012). Some studies have shown that the amount of nitrogen before flowering affects wheat grain protein content. It has a large regulatory effect (Desai et al., 1978) and some studies have shown that the contribution of nitrogen accumulation and operation amount before and after flowering to grain protein varies from species to species. The protein content has a regulating effect and the nitrogen accumulation after flowering mainly has a regulating effect on the grain protein content in medium protein varieties. There was a significant positive correlation between protein content in grains and nitrogen accumulation before flowering, and a significant or very significant positive correlation with grain/alcohol ratio, wet gluten content, water absorption, and quality of powder maps. The grain/alcohol ratio is an important index for evaluating the quality of wheat (Zou et al., 2006). The grain/alcohol ratio is related to water consumption during growth, nitrogen accumulation before flowering, wet gluten content, water absorption, dough formation time, and flour. There is a significant or very significant positive correlation between the mass numbers in the prime image. It can be seen that increasing the water consumption during the growth period and the amount of nitrogen accumulation before flowering are conducive to increasing the protein content of the grain, increasing the grain/alcohol ratio and ultimately facilitating the formation of quality. Under this test condition, the use of (WSS) is the most beneficial to improve the grain quality indicators such as protein and component content, grain/alcohol ratio, wet gluten content, water absorption, dough formation time and stabilization time.

\section{Effect of seeding rate on the regulation of yield amount}

Dry land wheat that sowing amount in open field was $354 \times 104 \mathrm{hm}^{-2}$, and $245 \times 104$ $\mathrm{hm}^{-2}$ on the film was good for improving grain yield (Feng et al., 2013). Suitable seeding rate for wide space sowing is $105 \mathrm{~kg} \cdot \mathrm{hm}^{-2}$. At this time, the highest yield of wheat is $13 \%$ higher than that of conventional precision sowing and the highest yield is $8643 \mathrm{~kg} \cdot \mathrm{hm}^{-2}$. 
A research work by Cao et al. (2008b) showed that the suitable nitrogen rate under trench sowing was $150 \mathrm{~kg} \cdot \mathrm{hm}^{-2}$ and the yield at this time was $8644 \mathrm{~kg} \cdot \mathrm{hm}^{-2}$. Under the conditions of this experiment the interaction effects of the sowing method and the sowing amount were analyzed: the sowing method, sowing amount, sowing method $\times$ the sowing amount had a significant effect on the number of ears, grain number, thousand-grain weight yield, and water use efficiency of winter wheat. Among them the most important influence on yield was the sowing method followed by the sowing amount; the most important effect on water use efficiency was the sowing amount, followed by the sowing method. The suitable seeding capacity for (WSS) was $300 \mathrm{~kg} \cdot \mathrm{hm}^{-2}$, the yield at this nitrogen amount was $7158 \mathrm{~kg} \cdot \mathrm{hm}^{-2}$ and the water use efficiency was $14.2 \%$; the suitable seeding capacity for trenching was $300 \mathrm{~kg} \cdot \mathrm{hm}^{-2}$. The yield at this sowing rate was $6343 \mathrm{~kg} \cdot \mathrm{hm}^{-2}$ and the water use efficiency was $13.4 \%$; the suitable nitrogen rate for uniform sowing was 375 $\mathrm{kg} \cdot \mathrm{hm}^{-2}$ and the yield at this sowing rate is $6780 \mathrm{~kg} \cdot \mathrm{hm}^{-2}$, the suitable sowing capacity for conventional sowing is $225 \mathrm{~kg} \cdot \mathrm{hm}^{-2}$, the yield at this sowing capacity was $5832 \mathrm{~kg} \cdot \mathrm{hm}^{-}$ 2 and the water use efficiency was $13.7 \%$. It can be seen that the appropriate nitrogen amount should be selected according to different nitrogen rate. Under this experimental condition, the matching nitrogen amount of (WSS) was $300 \mathrm{~kg} \cdot \mathrm{hm}^{-2}$, which is conducive to the improvement of grain yield and water use efficiency. It is suitable for the local sowing method and volume.

\section{Effect of seeding rate on $N$ input yield components and accumulation characteristics of dryland wheat}

Constructing a reasonable population structure, that is individuals can fully absorb water, light, heat and nutrient resources, promote the healthy growth of individuals, coordinate the contradictions between individual groups and it is extremely important for the coordination of wheat yield and quality (Bhatta et al., 2017; Lin et al., 1996). Nitrogen rate can affect the nitrogen accumulation and translation of winter wheat. Rational close planting of wheat is beneficial to increase nitrogen accumulation amount, so as to realize synergistic improvement of grain yield and nitrogen utilization efficiency. Enhanced nitrogen accumulation in winter wheat requires seeding rate at an appropriate density. Previous study indicated that with irrigation the winter wheat plant density increased from 270 to $405 \mathrm{~m}^{-2}$, nitrogen use efficiency (NUE) increased significantly mainly due to increasing root length density and enhanced nitrogen uptake (Dai et al., 2014).

Wheat grain nitrogen mainly comes from the redistribution of pre-anthesis nitrogen translocation amount from various organs, accounting for about 53.0\%, 80.8\% of grain nitrogen (Geleta et al., 2002). According to them the increase of nitrogen volume, the leaf area index (LAI) of Guomai 301 in the flowering stage gradually increased, the dry matter accumulation in the flowering stage increased first and then decreased and the number of ears and yield increased first and then decreased. Under the conditions of this experiment, the relevant analysis of factors related to yield formation shows that the water consumption during the growth period, the number of ears, the 1000 grain weight and the yield have a significant or very significant correlation and the nitrogen rate was 300 $\mathrm{kg} \cdot \mathrm{hm}^{-2}$. In the period the water consumption and the proportion of stored water consumption increased and the water consumption and irrigation water consumption decreased and the output gradually increased with the increase of the nitrogen amount. Increasing the sowing volume within a certain range increased the nitrogen accumulation in the above ground, the nitrogen utilization efficiency decreased and the nitrogen utilization increased first and then decreased (Zhu et al., 2018). 
A research by Zhang et al. (2015) showed that increasing planting density within a certain range increased nitrogen accumulation and absorption efficiency in the aboveground area and reduced nitrogen use efficiency. Wang et al. (2012) showed that with the increase of planting density, the nitrogen harvest index, grain accumulation and nitrogen content gradually decreased, and the contribution rate of nitrogen transport from vegetative organs to the grain during the flowering period showed an upward trend. Plant nitrogen accumulation wave, nitrogen absorption and utilization rate and nitrogen fertilizer partial production efficiency showed a trend of rising first and then decreasing. Xue et al. (2017) showed that increasing the sowing amount increased the amount of nitrogen accumulation in various organs before flowering and the contribution of nitrogen accumulation in leaves glumes and cobs to flowering increased before flowering. This study showed that with the increase of nitrogen rate the nitrogen accumulation of plants in each growth stage showed a trend of first increase and then decline and the contribution rate of nitrogen accumulation before flowering and the amount of nitrogen accumulation before flowering showed first contributions to grains. It reached the highest at $300 \mathrm{~kg} \cdot \mathrm{hm}^{-}$ 2. It can be seen that when the wide space sowing rate is $300 \mathrm{~kg} \cdot \mathrm{hm}^{-2}$, it is beneficial to improve accumulation of nitrogen in each growth period, increasing the contribution rate of nitrogen operation before flowering with grain, improving nitrogen absorption efficiency and nitrogen fertilizer production efficiency, are beneficial to plant nutrient operation. Adjusting the nitrogen rate to build a reasonable population structure, promoting wheat's absorption of soil moisture and nitrogen affect plant nutrient operation and thereby form protein in the grain. In the range of $245 \sim 330 \times 104 \mathrm{hm}^{-2}$, the grain protein content increased first and then decreased with increasing planting density. Under the conditions of this test a correlation analysis was performed and the protein content was extremely significantly positively correlated with the nitrogen accumulation and the grain/alcohol ratio before flowering. The change trend of first increase and then decrease reached the highest at $300 \mathrm{~kg} \cdot \mathrm{hm}^{-2}$, which may be due to the plant population under the nitrogen amount, low intercellular $\mathrm{CO} 2$ concentration, strong nitrogen metabolism, flag leaf GS and GOGAT activity, and grain GS activity. The GOGAT activity of the grain during the early grain filling period is high, the nitrogen accumulation is high before the flowering operation and finally the grain protein content increases (Wang et al., 2014).

\section{Conclusion}

Under this experimental condition, the matching nitrogen amount of WSS was $300 \mathrm{~kg} \cdot \mathrm{hm}^{-2}$, which is conducive to the improvement of grain yield and water use efficiency. It is suitable for the local sowing method and volume. Sowing methods are beneficial to the increase of winter wheat grain yield. Correlation analysis showed that there was a very significant positive correlation between yield and water consumption during the growing period, and nitrogen accumulation before flowering. Wide sowing increased water consumption during the growing period, and nitrogen transportation before flowering increased tiller number, leaf area in late growth period, dry matter accumulation in each growth period, and ear length. The water consumption during the growing period increases, the nitrogen accumulation and operation before flowering increases, the grain protein and component content increases, the grain/alcohol ratio increases, The effect of wide space sowing with $300 \mathrm{~kg} \cdot \mathrm{hm}^{-2}$ is the most obvious, and it is conducive to increasing water consumption in the growing period, increasing nitrogen accumulation in each growing period, and improving flowering. The amount of pre-nitrogen operation increases with the 
contribution of grains, improves nitrogen absorption efficiency and nitrogen fertilizer production efficiency, and promotes plant nutrient operation.

Acknowledgements. "Modern Agriculture Industry Technology System Construction” (No.CARS-3-124). The National Key Research and Development Program of China (No.2018YFD020040105). The Sanjin Scholar Support Special Funds Projects. National Natural Science Foundation of China (No. 31771727). The "1331" Engineering Key Innovation Cultivation Team-Organic Dry Cultivation and Cultivation Physiology Innovation Team (No. SXYBKY201733).

\section{REFERENCES}

[1] Berry, P. M., Griffin, J. M. (2000): Controlling plant form through husbandry to minimise lodging in wheat. - Field Crops Research. 67(1): 59-81.

[2] Bhatta, M. (2017): Seeding rate, genotype, and topdressed nitrogen effects on yield and agronomic characteristics of winter wheat. - Crop Science 57(2): 951-963.

[3] Cao, J. M., Zhang, J. T. (2008): Effects of different sowing quantity on wheat yield. Grassroots Agricultural Technology Promotion 6(06): 22-23.

[4] Chu, J., Zhu, W. (2018): Effects of wide-seeding on winter wheat 'Tainong 18' yield and nitrogen use efficiency. - Chinese Journal of Applied Ecology 29(08): 2517-2524.

[5] Crook, M. J., Ennos, A. R. (1995): The effect of nitrogen and growth regulators on stem and root characteristics associated with lodging in two cultivars of winter wheat. - Journal of Experimental Botany 46(289): 931-938.

[6] Cui, Z., Chen, X., Zhang, F. (2010): Current Nitrogen management status and measures to improve the intensive wheat-maize system in China. - Ambio 39(6): 376-384.

[7] Dai, X., Xiao, L. (2014): Increased plant density of winter wheat can enhance nitrogenuptake from deep soil. - Plant and Soil 384(1-2): 141-152.

[8] Dang, W., Ma, C. (2015): Effect of wide-range precision seeding on wheat yield and yield components. - Hebei Agricultural Sciences 19(02): 15-17.

[9] Deng, X. P., Shan, L. (2006): Improving agricultural water use efficiency in arid and semiarid areas of China. - Agricultural Water Management 80(1-3): 23-40.

[10] Desai, R. M. (1978): Nitrogen uptake and nitrogen harvest index in durum wheat cultivars varying in their grain protein concentration. - Euphytica 27(2): 561-566.

[11] El Mejahed, K., Aouragh, L. (2005): Green manure and $n$ fertilizer in soil quality and profitability of wheat based system in semiarid Morocco using nuclear techniques. - In: Nutrient and Water Management Practices for Increasing Crop Production in Rainfed Arid/Semi-Arid Areas. Proceedings of a Coordinated Research Project. TECDOC-1468, IAEA, Seibersdorf, pp. 89-106.

[12] Feng, C. N., Guo, W. S., Wang, F. T., Zhu, X. K., Peng, Y. X. (1999): Mechanism of the population formation with high grain-leaf ratio in wheat. - Scientia Agricultura Sinica 32(6): 47-55.

[13] Feng, R., Guo, A. (2013): Effects of different wide-seeded wheat sowing on population dynamics and yield. - Journal of Henan University of Science and Technology (Natural Science Edition) 41(02): 6-8.

[14] Fu, Q., Wang, Q., Shen, X., Fan, J. (2014): Optimizing water and nitrogen inputs for winter wheat cropping system on the Loess Plateau, China. - Journal of Arid Land 6(2): 230-242.

[15] Gardner, W. H. (1986): Methods of Soil Analysis. Part 1. Physical and Mineralogical Methods. - Soil Science Society of America, Inc., Madison, WI, pp. 493-544.

[16] Geleta, B., Atak M. (2002): Seeding rate and genotype effect on agronomic performance and end-use quality of winter wheat. - Crop Science 42: 827-832. 
[17] Goffart, J. P., Olivier, M. (2008): Potato crop nitrogen status assessment to improve N fertilization management and efficiency: past-present-future. - Potato Research. 51(3-4): 355-83.

[18] Gonzalez Dugo, V. (2010): Water deficit and nitrogen nutrition of crops. A review. Agron. Sustain. Dev. 30: 529-544.

[19] Grigoras, M. A., Popescu, A., Pamfil, D., Has, I., Gidea, M. (2012): Influence of no-tillage agriculture system and fertilization on wheat yield and grain protein and gluten contents. Journal of Food, Agriculture and Environment 10(2): 539Article 852.

[20] Guarda, G., Padovan, S. (2004): Grain yield, nitrogen-use efficiency and baking quality of old and modern Italian bread-wheat cultivars grown at different nitrogen levels. - European J. Agron. 21: 181-192.

[21] Haruna, I. M. (2011): Growth and yield of sesame (Sesamum indicum L.) as influenced by nitrogen and intra row spacing in Lafia, Nasarawa state of Nigeria. - Elixir Agriculture 41: $5685-5688$.

[22] He, J., Kuhn, N. J., Zhang, X. M. (2009): Effects of 10 years of conservation tillage on soil properties and productivity in the farming-pastoral ecotone of Inner Mongolia, China. Soil Use and Management 25(2): 201-209.

[23] Hou, H., Gao, S. (2017): Water consumption characteristics of spring wheat in fullmembrane soil cultivation in dry land and its effect on yield. - Journal of Soil and Water Conservation 31(01): 202-210.

[24] Jin, K., Cornelis, W. M., et al. (2007): Effects of different management practices on the soil-water balance and crop yield for improved dryland farming in the Chinese Loess Plateau. - Soil \& Tillage Research 96(1-2): 131-144.

[25] Ju, X. T., Kou, C. L. (2006): Nitrogen balance and groundwater nitrate contamination: comparison among three intensive cropping systems on the North China Plain. - Environ. Pollut. 143: 117-125.

[26] Kang, S., Zhang, L., Liang, Y. (2002): Effects of limited irrigation on yield and water use efficiency of winter wheat in the Loess Plateau of China. - Agric. Water Manag. 55: 203216.

[27] Lei, M., Sun M. (2017): The effect of water-soaked and suitable seeding in dry season on wheat yield in dryland. - Chinese Agricultural Science 50(15): 2904-2915.

[28] Li, G., Shi, Y. (2012): Effects of subsoil and tillage on post-anthesis root senescence and yield of dryland wheat. - Journal of Triticeae Crops 32(3): 500-502.

[29] Li, S. X. Wang, Z. H. (2009): Nutrient and water management effects on crop production, and nutrient and water use efficiency in dryland areas of China. - Advances in Agronomy 102: 223-265.

[30] Li, S. X., Wang, Z. H. (2015): Effect of nitrogen fertilization under plastic mulched and non-plastic mulched conditions on water use by maize plants in dryland areas of China. Agricultural Water Management 162: 15-32.

[31] Li, S., Zhang, Y. (2015): The effect of wide band sowing on the water consumption characteristics of winter wheat. - Henan Agricultural Sciences 44(02): 22-27.

[32] Lin, C. C., Kao, C. H. (1996): Disturbed ammonium assimilation in associated with growth inhibition of roots in rice seedlings caused by NaCl. - Plant Growth Regulation 18(3): 233238.

[33] Liu, L., Zhang, S. (2012): Study on the suitable sowing dates and sowing rates of different sowing methods for dryland wheat in the Southwest of Shanxi. - Wheat Research 33(02): $11-22$.

[34] Liu, L., Xu, B C., Li F. M. (2007): Effects of limited irrigation on yield and water use efficiency of two sequence-replaced winter wheat in Loess Plateau, China. - African Journal of Biotechnology 6(13): 1493-1497.

[35] Liu, X., Wu, C. (2015): Compensation effect of yield loss and water use efficiency of widerow precision sowing winter wheat under corn stalk cover. - Journal of Drainage and Irrigation Machinery Engin 33(09): 811-817. 
[36] López-Bellido, L. (2013): Nitrate accumulation in the soil profile: long-term effects of tillage, rotation and $\mathrm{N}$ rate in a Mediterranean Vertisol. - Soil Till. Res. 130: 18-23.

[37] Madani, A., Shirani-Rad, A. (2010): Wheat (Triticum aestivum L.) grain filling and dry matter partitioning responses to source:sink modifications under postanthesis water and nitrogen deficiency. - Acta Scientiarum Agronomy. 32(1): 145-51.

[38] Mao, Y., Lei B. (2015): Effects of different no-till mulch cultivation models on the adaptation of Yunnan spring potato to seasonal drought. - Soil Bulletin 46(3): 556-561.

[39] Meyer, J. (1983): Rapid determination of nitrogen in cane leaves. - Proceedings of the South Ajican Sugar Technologists' Association, pp. 109-112.

[40] Myrbeck, Å. (2014): Soil tillage influences on soil mineral nitrogen and nitrate leaching in swedish arable soils. - Doctoral Dissertation, Swedish University of Agricultural Sciences, Uppsala, Sweden.

[41] Noor, H., Khan, S., Min, S., Yu, S. (2020): Effect of different sowing methods and Nitrogen rates on Yield and Quality of winter wheat in loess plateau of China. - Applied Ecology and Environmental Research 18(4): 5701-5726.

[42] Parry, M. A. J., Reynolds, M. (2011): Raising yield potential of wheat. II. Increasing photosynthetic capacity and efficiency. - J. Exp. Bot. 62: 453-467.

[43] Przurj, N. et al., (2003): Dry matter and nitrogen accumulation and use in spring barley. Plant, Soil and Environment. 49(1): 36-47.

[44] Robertson, G. P., Vitousek, P. M. (2009): Nitrogen in agriculture: balancing the cost of an essential resource. - Annu. Rev. Environ. Resour. 34: 97-125.

[45] Schlegel, A. J., Assefa, Y., Haag, L. A., Thompson, C. R., Holman, J. D., Stone, L. R. (2017): Yield and soil water in three dryland wheat and grain sorghum rotations. Agronomy Journal 109(1): 227-238.

[46] Sieling, K. (1997): Effect of slurry application and mineral nitrogen fertilization on $\mathrm{N}$ leaching in different crop combinations. - J. Agric. Sci. 128: 79-86.

[47] Tavakkoli, A. R., Oweis, T. Y. et al., (2004): The role of supplemental irrigation and nitrogen in producing bread wheat in the highlands of Iran. - Agr. Water Manage. 65: 225236.

[48] Turner, N. C., Asseng S. (2005): Productivity, sustainability, and rainfall-use efficiency in Australian rain fed Mediterranean agricultural systems. - Australian Journal of Agricultural Research 56: 1123-1136.

[49] Wang, K. (2012): Effect of wide-range precision seeding on photosynthetic characteristics and yield of winter wheat. - Agricultural Science and Technology Newsletter 9: 60-62.

[50] Wang, N., Wang, J. (2014): Yield and quality of wheat "Jiumai 2" with different sowing dates and sowing rates. - Chinese Agricultural Science Bulletin 30(21): 80-84.

[51] Wang, S., He, M. (2012): Effects of planting density on nitrogen absorption and distribution in winter wheat. - Chinese Journal of Eco-Agriculture 20(10): 1276-1281.

[52] Xue, L., Sun, M. (2017): Effects of incremental subsurface water storage sowing of dryland wheat on plant nitrogen use and grain yield and protein formation. - China Agricultural Science 50(13): 2451-2462.

[53] Xue, L., Khan, S., Sun, M. (2019): Effects of tillage practices on water consumption and grain yield of dryland winter wheat under different precipitation distribution in the loess plateau of China. - Soil and Tillage Research 191: 66-74.

[54] Yan, W., Deng, L., Zhong, Y., Shangguan, Z. (2015): The characters of dry soil layer on the loess plateau in China and their influencing factors. - PLoS ONE 10(8): e0134902.

[55] Yu, S., Yong, Z., Li, Y. (2009): Contents of grain protein components and their relationships to processing quality in wheat. - Acta Agronomica Sinica 35: 13061312.

[56] Zecevic, V., Knezevic, D. (2005): Wheat mineral nutrition and quality. - International Conference on Sustainable Agriculture and European Integration Processes, Novi Sad. Contemporary Agriculture, Novi Sad. 54: 613-618. 
[57] Zhang, J., Wu. D. H., et al. (2015): Effects of planting density and nitrogen application level on soil nitrogen uptake and utilization of wheat. - Ying Yong Sheng Tai Xue Bao 26(6): 1727-1734.

[58] Zhang, Y., Yang, W., Bai, J. (2007): Characteristics of synergistic changes in winter wheat yield and grain protein content and water and fertilizer regulation. - China Agricultural Sciences 39 (12): 2449-2458.

[59] Zhao, M., Zhou, X. (2006): Characteristics of nitrogen accumulation, distribution and translocation in winter wheat on dryland. - J. Plant Nutrition and Fertilizer Science 12: 143-149.

[60] Zhu, W., Fei, L. (2018): Effects of planting density on winter wheat yield, nitrogen utilization rate and water use efficiency under rainfed and irrigation conditions. - Shandong Agricultural Sciences 50(08): 35-41.

[61] Zhu, Z. L., Norse, D. (2006): Policy for Reducing Non-point Source Pollution from Crop Production in China. - China Env. Sci. Press, Beijing, pp. 135-299.

[62] Zou, T., Dai, T. (2006): Effects of potassium levels on nitrogen accumulation and movement and grain protein formation in wheat. - China Agricultural Sciences 39(4): 686692. 